Review Article

\section{Applications of contemporary imaging modalities in orthodontics}

 \\ ${ }^{1}$ Department of Dentomaxillofacial Orthodontics, Faculty of Dentistry, Medipol University, Istanbul, Turkey \\ ${ }^{2}$ Department of Dentomaxillofacial Radiology, Faculty of Dentistry, Ankara University, Ankara, Turkey
}

$\mathrm{J}$ Exp Clin Med

2021; 38(S2): 104-112

doi: 10.52142/omujecm.38.si.dent.5

Received: $10.05 .2020 \quad \bullet \quad$ Accepted/Published Online: 09.12.2020

Final Version: 19.05.2021

\begin{abstract}
The validity of orthodontic diagnosis and treatment planning depends on the accuracy of the photos, models and radiograps to be obtained from the patient. One of the most important parts of diagnosis and treatment planning is the use of appropriate imaging method. Although lateral cephalometric radiographs are still the most preferred imaging method, other methods such as hand-wrist radiographs, panoramic radiographs, cone beam computerized tomography (CBCT), magnetic resonance imaging (MRI), and ultrasound are also frequently used. For this reason, it is important to know the advantages and disadvantages of all imaging methods for orthodontists in order to select the most suitable method for the patient. Although 2D imaging modalities are still frequently preferred in terms of their accessibility, CBCT use may come to the fore when precise imaging of hard tissues is desired. In cases where TMJ region and soft tissues are to be imaged, the use of MRI and ultrasound should be considered. Orthodontists should follow up the up-to-date usage areas of the developing imaging methods.
\end{abstract}

Keywords: CBCT, contemporary imaging, digital imaging, orthodontics, 3D Imaging

\section{Introduction}

Orthodontic treatment aims to position the dentition within the skeletal and soft tissue environment for optimal facial and dental aesthetics. Although the design of primitive orthodontic appliances dated back to ancient times, systematic identification of orthodontics was carried out by Kingsley in the 1800s (Kingsley, 1880; Profitt, 2013). The occlusion concept, which simply expresses contact between teeth, was introduced in the late $1800 \mathrm{~s}$, and the classification of this relationship was carried out by Edward H. Angle, the father of modern orthodontics (Angle, 1899; Angle, 1907). This classification, which was mainly based on the relationship of molar teeth, had been effective in the transition of orthodontic treatments to a more advanced stage. Nevertheless, it was observed that satisfactory results could not be achieved due to incompatibilities in the jaw and facial structures even if ideal occlusion was achieved. With the spread of lateral cephalometric radiographs after World War II, it had been shown that the problem in Class II and Class III malocclusions was not only due to the placement of the teeth, but also the position of the jaws was effective in this case. Therefore, the treatments started to target not only the correction of the teeth but also the correction of the skeletal structure (Profitt, 2013).

The validity of orthodontic diagnosis and treatment planning depends on the completeness of the material to be obtained from the patient. One of the most important parts of diagnosis and treatment planning is the use of appropriate imaging method. Although lateral cephalometric radiographs are still the most used imaging method, other methods such as hand-wrist radiographs, panoramic radiographs, cone beam computerized tomography (CBCT), magnetic resonance imaging (MRI), and ultrasound are also frequently used. The important thing is that the orthodontist should decide which radiographs are required to suit the needs of each patient.

\section{2D imaging modalities}

\subsection{Lateral cephalometric radiographs}

Cephalometry was a tool used by anatomists for measuring skulls and studying craniofacial development long before the emergence of orthodontic science (Chaconas and Fragiskos, 1991; Uzel and Enacar, 2000). For the first time, Pacini (1922) obtainted lateral cephalometric films by fixing the individuals' heads with bandages, and made some dimensional and angular measurements on these films for anthropometric purposes and investigated certain indices. Later in 1931, standardized remote $\mathrm{X}$-ray techniques were developed by Hofrath in Germany to examine the results of prosthodontic reconstruction, and by Broadbent in the USA to study craniofacial growth. In this way, cephalometry had entered clinical use and had become one of the most important tools of orthodontic clinic and 
research (Uzel and Enacar, 2000; Quintero et al., 1999; Profitt, 2013; Hans et al., 2015).

After the cephalometry entered the orthodontic literature in 1931, analysis methods were developed one after another. Researchers such as Tweed, Downs, Steiner, Sasounni, Ricketts, Jarabak and Fizzell, McNamara created cephalometric analysis methods (Uzel and Enacar, 2000). Cephalometric films are generally obtained in the head position, where the Frankfort Horizontal plane, clinically detected, is parallel to the ground, where the head is fixed with the ear and nasion sticks of the cephalostat. Cephalometric analysis is carried out according to the various reference planes obtained using intracranial points on these films. Some hard tissue reference points used in cephalometric analysis are exemplified in Fig. 1.

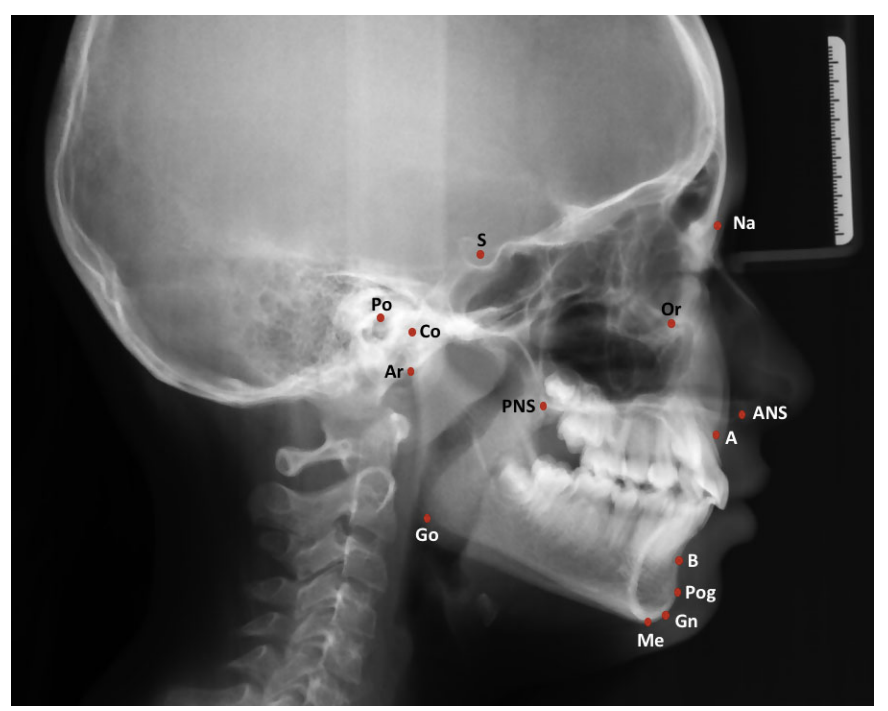

Fig. 1. Examples for cephalometric hard tissue landmarks. A: The deepest point of concavity on the maxilla between ANS and prosthion. B: The deepest point of concavity on the mandibular symphysis between infradentale and pogonion. Na: Nasion, the most anterior point of the front nasal suture. S: Sella, the midpoint of sella turcica. Go: Gonion, point of intersection of the ramus plane and the mandibular plane. Me: Menton, the midpoint on the inferior border of the mental protuberances. Pog: Pogonion, the most anterior point of the bony chin in the median plane. Gn: Gnathion, the most anteroinferior point on the symphysis. ANS: the most anterior point of anterior nasal spine. PNS: the most posterior point of posterior nasal spine. Po: Porion, The most superior point of the meatus acusticus externus. Co: Condylion, most posterior/superior point on the condyle of mandible. Or: Orbitale, most inferior point on margin of orbit. Ar: Articulare, junction between inferior surface of the cranial base and the posterior border of the ascending rami of the mandible

Cephalometric analysis methods are used for orthodontic diagnosis, to determine facial growth patterns, to evaluate changes during and after orthodontic treatment. (Ülgen, 2001; Kayasu and Köklü, 2012). Current uses of cephalometry are (Gill and Naini):

Morphological analysis: Orthodontic anomalies arise not only from the positional disorders of the teeth, but also from the size and position of jaws and facial structures. Cephalometric analysis methods are frequently used to make the correct diagnosis. Various linear and angular measurements are used for this purpose. Thus, the relationship between the jaws with each other and the cranial base can be evaluated in both sagittal and vertical directions. Cephalometric analysis is used not only for the evaluation of skeletal structure but also for the evaluation of dental relations and soft tissue (Holdaway, 1983; Bergman, 1999).

Analysis of facial growth pattern: Accurate diagnosis of facial growth pattern is to determine the treatment timing and the appropriate treatment method. It is not possible to stop growing, but it is possible to direct it with appropriate treatment mechanics. Therefore, various measurements can be used to determine the treatment method that will not conflict with the patient's growth model and can give an effective result (Erverdi, 2017).

Evaluation of treatment results: Cephalometric analysis can be used not only in diagnosis, but also to evaluate the effect of functional appliances and other treatment mechanics,

Evaluation of impacted teeth: Although panoramic radiographs and 3D imaging methods are frequently preferred for this purpose, cephalometric radiographs can also be used to have an idea about the bucco-lingual positions of anterior teeth.

Evaluation of skeletal maturation: It is very important to determine the skeletal development of the individuals to treat the anomalies related to the lower and middle face areas at the appropriate time. In treatments targeting growth modifications, the most appropriate period is considered to be the pubertal peak period. Although different methods are used to evaluate the skeletal maturation of individuals, one of the most frequently used methods is the evaluation of cervical vertebra maturation stages (CVMS) on lateral cephalometric radiographs. CVM stages were first introduced by Lamparski (1972). Then Baccetti et al. (2002) developed the method, by examining the shape and size of the bodies of the cervical vertabrae 2-4. They have identified five maturation stages. Baccetti et al. (2005) evaluated CVM phases in six groups in another study (Fig. 2). Studies showed that this method was reliable in predicting individual growth and evaluating the growth spurt of the mandible (Hassel and Farman, 1995; Flores-Mir et al., 2006; McNamara and Franchi, 2018). The most important advantage of the method is that it does not need any other material in addition to cephalometric radiographs, it is easy to apply and practical. However, it should be kept in mind that it is subjective because of visual evaluation (Türköz et al., 2017).

\subsection{Hand-wrist radiographs}

One of the most frequently used methods for determining skeletal maturation is the evaluation of hand-wrist radiographs. The presence of a large number of bones in the region and its ability to provide detailed assessment often make it preferred 
compared to other methods (Bowden, 1976; Fishman, 1979). Evaluation of skeletal maturation using hand-wrist radiographs can be performed with two approaches.

First approach is based on comparison of radiographs for determining the skeletal age of individuals using hand-wrist atlas. The atlas of Greulich and Pyle (1959) contains hand and wrist radiographs, taken from girls and boys, from birth to adulthood, with an interval of six months. Each bone of the patient's hand-wrist is compared with the corresponding bones in the atlas and is assigned an age in months. In this atlas, again for girls and boys separately; separate tables are given for skeletal age as normal, retarded or accelerated. These tables show how many percent of the child's growth is completed at each age. In Tanner et al. (1983) method, specific ossification centers in the hand and wrist (radius, ulna and certain metacarpal and phalanges) are evaluated and classified for certain stages. The total bone age is determined by calculating the score obtained from each bone.
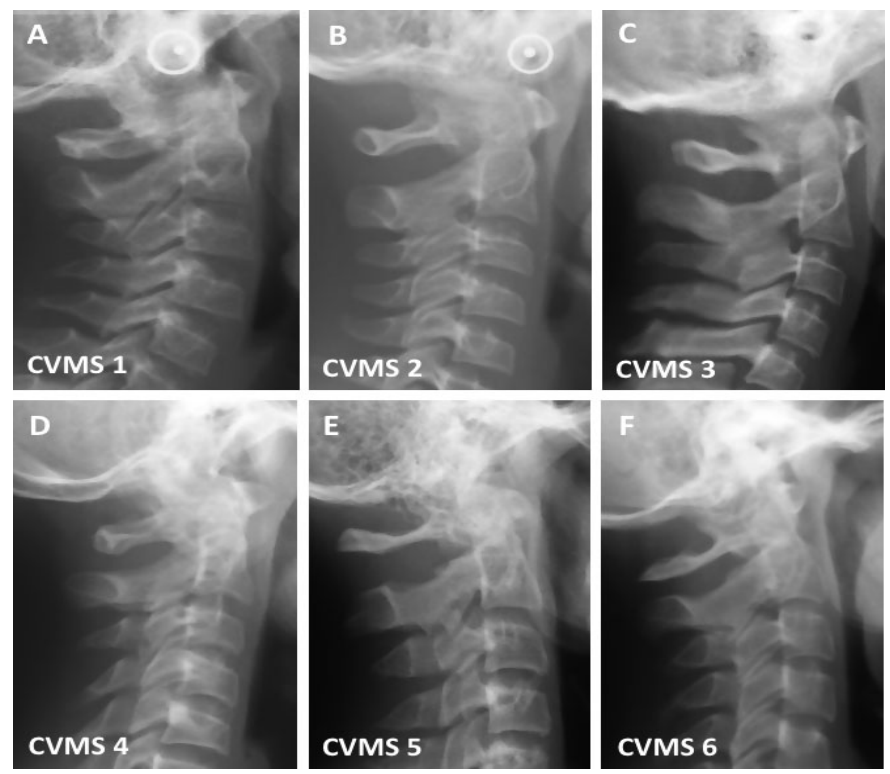

Fig. 2. Cervical vertebrae maturation stages. A. CVMS 1: Inferior surfaces of all vertebras are flat and get narrower from posterior towards anterior. B. CVMS 2: Formation of a concavity at the lower border of the second vertebra has started and anterior heights of the vertebras have increased. C. CVMS 3: Lower border of the third vertebra is also becoming concave. D. CVMS 4: Lower border of the fourth vertebra is also concave and slight concavity is observed at the fifth and sixth vertebras. Also, vertebras are now rectangular in shape at this stage. E. CVMS 5: Concavity of the fifth and sixth vertebras has distinctively deepened, vertebras are rectangular in shape and the gap between them has decreased. F. CVMS 6: Length of the vertebras exceeds their width and concavities are deep (Baccetti et al., 2002)

The second approach aims to reveal the skeletal development period of the individual by evaluating the formation of various hand bones and the epiphysis/diaphysis relationship on hand-wrist radiographs. The expansion of the epiphyses is associated with diaphysis and is an ongoing process. The epiphysis first emerges as the ossification center in the middle of the diaphysis and begins to expand to the sides. The capping phase is the phase between the expansion of the epiphyses and their union with the diaphysis. The formation of the sesamoid bone begins on the medial of the proximal phalanx of the thumb (Fishman, 1982). The formation of the sesamoid bone occurs about 1 year before the pubertal peak. Pubertal peak growth is considered as the period when the epiphysis of the medial phalanx of the $3^{\text {rd }}$ finger is capping through the diaphysis (MP3cap). The evaluation of the growth period by evaluating ulnar, radius, carpal, metacarpals, phalanges, and the sesamoid bone on hand-wrist radiographs was examined by various researchers and various classifications was introduced (Bjork and Helm, 1967; Bowden, 1976; Fishman, 1982). These methods aimed to determine the treatment approach by evaluating the skeletal maturation of the individual, not the calculation of the skeletal age. Examples of hand-wrist radiographs showing various stages are presented in Fig. 3.

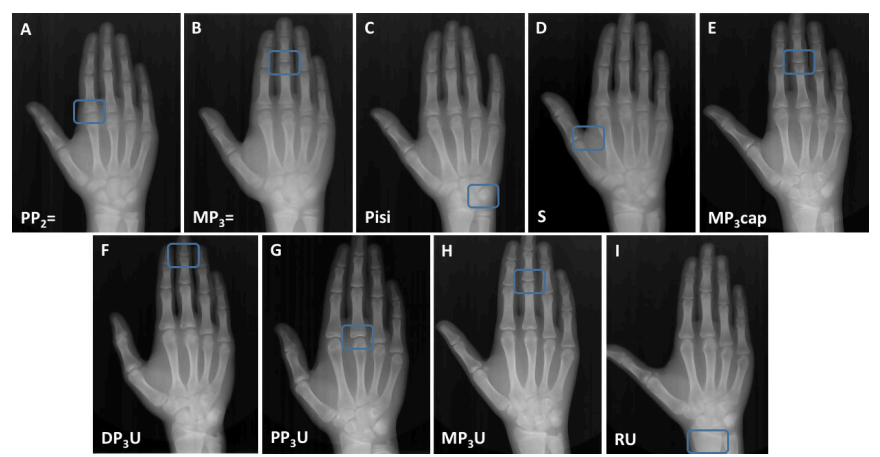

Fig. 3. Stages of maturation according to the hand wrist radiographs. A. $\mathrm{PP}_{2}=$ (equality of epiphysis and diaphysis of proximal phalanx of the $2^{\text {nd }}$ finger), $\mathrm{B} . \mathrm{MP}_{3}=$ (equality of epiphysis and diaphysis of medial phalanx of the 3rd finger), C. Pisi (ossification of os pisiforme), D. S (formation of the sesamoid bone), E. $\mathrm{MP}_{3}$ cap (epiphysis of medial phalanx of the $3^{\text {rd }}$ finger covering diaphysis), F. $\mathrm{DP}_{3} \mathrm{U}$ (fusion of epiphysis and diaphysis of distal phalanx of the $3^{\text {rd }}$ finger), G. $\mathrm{PP}_{3} \mathrm{U}$ (fusion of epiphysis and diaphysis of proximal phalanx of the $3^{\text {rd }}$ finger), $\mathrm{H} . \mathrm{MP}_{3} \mathrm{U}$ (fusion of epiphysis and diaphysis of medial phalanx of the $3^{\text {rd }}$ finger), I. RU (Fusion of radial epiphysis with diaphysis)

\subsection{Panoramic radiographs}

Panoramic radiography is the technique that provides a single tomographic image of the facial structures containing both the maxillary and mandibular dental arches and the tissues that support them. Panoramic radiographs have the advantages of being able to apply in patients who cannot open their mouth, showing teeth, mandible and maxillary and a large part of other facial bones together, having a much lower radiation dose compared to full mouth periapical films, and completion in a short time (Orhan and Aksoy, 2015).

Panoramic radiographs are frequently used for orthodontic diagnosis and treatment planning. Panoramic radiographs provide an extensive examination of the patient's temporomandibular joint, including all maxillary and mandibular arches. These radiographs can be used to detect dental anomalies, to detect hypodontia and supernumerary teeth, and to evaluate impacted teeth. (Graber 1967; Altug and Erdem, 2007). Panoramic radiographs can also be used to detect variations in root morphology and resorption (Apajalahti 
and Peltola, 2007). Diagnostic features of panoramic radiographs for the evaluation of skeletal pattern were evaluated by various researchers (Akçam et al., 2003; Nohadani and Ruf, 2008). Although some parameters were shown to be useful, their reliability was found to be low. Therefore, cephalometric radiographs should be preferred in determining the skeletal pattern. Panoramic radiographs are also helpful in assessing the quality and quantity of alveolar bone for placement of temporary anchorage devices (TAD) and implants, and in determining their distance to vital structures.

\section{3D imaging modalities}

Three-dimensional (3D) imaging methods have found widespread use in orthodontics, as in other areas of dentistry in recent years. It has been frequently emphasized in previous studies that two-dimensional images are insufficient to reflect the three-dimensional cranial system. 2D imaging methods may be insufficient to reflect anatomical asymmetry, and errors in head positioning can cause distortion of the image (Hans et al., 2015). For example, while determining the "mandibular plane" used in cephalometric analysis, an imaginary plane is created by averaging the right and left lower borders of the mandible. Especially in such cases where bilateral structures are averaged, it is difficult to make accurate evaluation of the patient (Palomo et al., 2005). Therefore, 3D imaging modalities are becoming increasingly common in the visualization of both hard and soft tissue, in orthodontic practice.

\subsection{Computed Tomography (CT)}

CT was developed by Godfrey Hounsfield in 1972 and basically consists of a well-collated X-ray tube that produces a fan-shaped X-ray, scintillation detectors that measure the number of photons that pass through the patient, and orientation chambers. Since CT allows the imaging of normal and abnormal soft tissues and bone tissues, it is useful in the evaluation of temporomandibular joint (TMJ) diseases, the evaluation of syndromes and deformities associated with craniofacial region and the decision of treatment plan before maxillofacial and orthognathic surgery. Compared to conventional imaging methods, CT is advantageous for allowing the 3D examination of structures without superposition of surrounding tissues, having high contrast resolution which allows two tissues with different physical density to be separated more easily, having no distortion and magnification. Meanwhile, the need to use contrast agents to display soft tissues, high radiation dose, and reduced image quality due to the scattering in the image caused by metallic objects are considered to be the main disadvantages of CT imaging (Orhan and Aksoy, 2015).

\subsection{Cone Beam Computed Tomography (CBCT)}

The high cost and the high radiation dose of conventional CTs prevented their use in dentistry routine in spite of method's high image quality. Mozzo et al. (1998) introduced CBCT to overcome these disadvantages of CTs. Today, CBCT is frequently preferred as a routine clinical procedure because it takes up less space, its cost is much lower than CT and the radiation dose is less (Erten and Yilmaz, 2018). For CBCT imaging, instead of the fan-shaped X-ray used in CT, the conebeam X-ray photons are used. The shape of the beam can be circular or rectangular. Unlike the multiple rotation used to obtain images in a spiral CT, a single $360^{\circ}$ rotation is sufficient to display the relevant area in the CBCT. In this way, X-rays are used more efficiently, and 3D images are obtained with the use of much less X-ray components (Orhan and Aksoy, 2015).

Ionizing radiation is a known human carcinogenic factor and its biological effects are more important in young patients because of their higher radiosensitivity. Although the radiation dose to which the patient is exposed is much lower in CBCTs, indications for the use of CBCT should be well established in orthodontics, especially in the pediatric population. American Academy of Oral and Maxillofacial Radiology (AAOMR) (2013) stated that exposure of patients to ionizing radiation must never be considered "routine" and it is important to perform a thorough clinical examination prior to performing or ordering any radiographic study.

Oenning et al. (2018) introduced the DIMITRA (dentomaxillofacial pediatric imaging: an investigation toward low-dose radiation-induced risks) project and justified the importance to move from the principles of ALARA (As Low as Reasonably Achievable) and ALADA (As Low as Diagnostically Acceptable) to ALADAIP (As Low as Diagnostically Acceptable being Indication-oriented and Patient-specific). In this report, it is reported that CBCTs can be used for the evaluation of impacted and supernumerary teeth. Binita et al. (2010) stated that CBCTs can provide more detailed information in the initial diagnosis of pathologies such as impacted and supernumarary teeth than traditional radiographs. CBCTs may also be preferred in cases where it is necessary to determine bone quality and distance to anatomical structures such as placing temporary anchorage devices or evaluating orthodontic treatment results.

Another area in which CBCTs are used in orthodontics is the determination of root resorptions. Dudic et al. (2009) evaluated the resorption of 275 teeth in 22 individuals with panoramic radiographs and CBCTs. They concluded that apical root resorption after orthodontic tooth movement is underestimated when evaluated on panoramic radiography. CBCT can be considered as a useful diagnostic method compared to conventional radiography. There are many craniofacial anomalies that affect facial morphology and the development of the maxilla/mandible. In craniofacial syndromes, the response to treatment varies depending on the pathogenesis of the underlying anomaly. Another area in which CBCT is beneficial is the ability to display defects in detail in anomalies such as cleft lip and palate and provide detailed imaging of craniofacial morphology in the presence of the syndrome associated with cranial region (Garib et al., 2012; 
Dalessandri et al., 2011). Depending on the superiority of CBCTs in hard tissue imaging, CBCT can be preferred to visualize the bone component of temporomandibular joint region such as glenoid fossa, condyle morphology, articular eminence (Sümbüllü et al., 2012; Ejima et al., 2013).

The upper airway affects the growth and development of the jaws. Determination of airway dimensions is limited in conventional 2D cephalometric images. Meanwhile, CBCT allows 3D visualization and volumetric analysis of the upper airway and provides reliable results (Zimmerman et al., 2019). In adults with skeletal incompatibility between the jaws, ideal treatment is orthognathic surgery. Especially in recent years, $3 \mathrm{D}$ imaging methods and softwares produced for this purpose have increased remarkably for orthognathic surgery planning and follow-up. Sharath Kumar et al. (2017) stated that 3D virtual head models are accurate and realistic tools for documentation, analysis, treatment planning and long term follow up for orthognathic surgery procedures and may provide a realistic prediction model.

With the introduction of CBCT in craniofacial imaging, it provided detailed/3D imaging and measurement opportunities in many areas of orthodontics. However, the accuracy of the measurements obtained from CBCT should be investigated when used in these areas. While investigating the accuracy and consistency of the linear and angular measurements of the CBCT, it was compared with the measurements made with the help of a skull caliper. Although there were minor differences in some measurements, it has been reported that cephalometric radiographs created from images taken with CBCT can be used instead of conventional methods (Van Vlijmenet al., 2010). Navarro et al. (2013) compared the manual, digital and lateral CBCT cephalometric analyzer. According to their results, all evaluated methods were reliable and valid, however, the lateral cephalograms from the CBCTs proved the most reliable. In another study, Cattaneo et al. (2008) aimed to compare conventional and cone-beam computed tomography generated cephalograms. They concluded that CBCT-synthesized cephalograms can successfully replace conventional radiographs. Many studies reported that CBCTs may be an alternative to conventional radiographs and are superior in many ways. However, when deciding on the imaging method, the simplest technique which providing the necessary information, but protecting the patient rom unnecessary radiation, should be preferred.

\subsection{Magnetic Resonance Imaging (MRI)}

MRI is based on the principle of creating a signal by inserting hydrogen atoms, which are densely present in water and adipose tissue, into a strong magnetic field by vibrating with radiofrequency (RF) energy (Oyar, 2008). The absence of ionizing radiation, taking images on any desired plane without changing the patient's position, and having a high soft tissue discrimination power have made MRI an important imaging method in medical practice. However, the technique's high sensitivity to movement, high cost of the imaging and the difficulty for claustrophobic patients was demonstrated as factors limiting the use of MRI. (Brown and Semelka, 1999; White et al., 2000; Könez, 1995).

The fact that different tissue densities can be displayed with high contrast sensitivity without giving ionizing radiation to the patient has extended MRI applications especially in the examination of soft tissues (Orhan et al. 2006; Ozbek et al, 2016). MRI is accepted as the gold standard in the imaging of the TMJ region along with the arthrography (Orhan et al., 2005; Orhan et al., 2006) (Fig. 4). The advantages such as high diagnostic quality of MRI in the TMJ region, being pain-free and non-invasive, and no ionizing radiation to the patient have allowed it to be used for the evaluation of spatial changes occurring in the joint area with functional orthopedic treatment (Ruf and Pancherz, 1998; Pancherz et al., 1999; Ruf et al., 2002; Cesur et al., 2020).
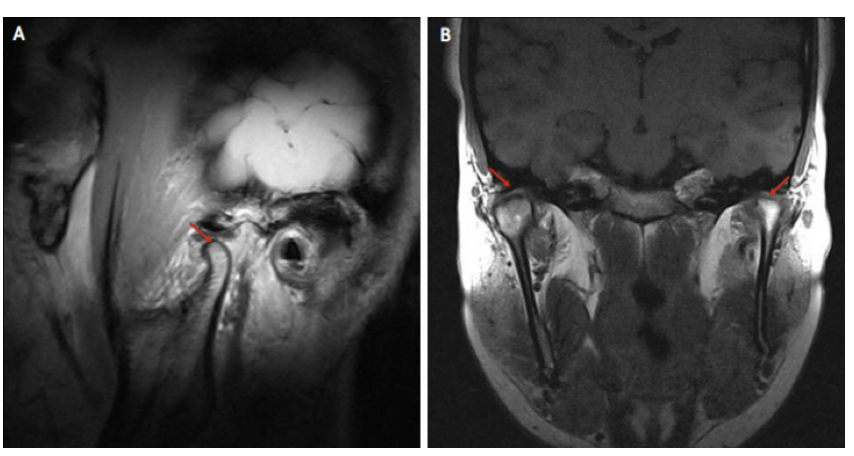

Fig. 4. Imaging of the TMJ region and mandibular condyle in sagittal (A) and coronal (B) sections on MR images

Method's high ability in soft tissue imaging also allows the visualization of masticatory muscles. Orhan et al. (2005) determined an increase in signal intensity ratio (SIR) in lateral pterygoid and temporal muscle activity in patients with disc displacement. Boom et al. (2008), on the other hand, examined the relationship between masseter and medial pterygoid muscle volumes and the vertical size of the face and stated that there was a strong correlation between these muscles and the posterior facial height. MR imaging of the masticatory muscles is exemplified in Fig. 5. Studies conducted in recent years revealed that, MRI also enables cephalometric analysis (Eley et al., 2012; Eley et al., 2013; Markic et al., 2014; Heil et al., 2017). Markic et al. (2014) compared the efficacy of panoramic radiography, cephalometric radiography, MRI, CBCT and CT using cadaveric human heads in evaluating the length of the mandibular ramus and condylar process, and reported that all $3 \mathrm{D}$ imaging methods gave similar results. Accordingly, the researchers recommended the use of MRI as it is non-ionizing. Eley et al. (2012) described a low flip angle gradient echo MRI sequence which provides high image contrast between bone and other tissues but reduces the contrast between individual soft tissues. This permits the " black bone 'to be easily distinguished from the uniformity of the soft tissues. They claimed that "Black Bone" MRI offered an improved method of cephalometric landmark identification 
over routine MRI sequences, and provides a potential nonionizing alternative to $\mathrm{CT}$ for three-dimensional cephalometrics (Eley et al., 2013).

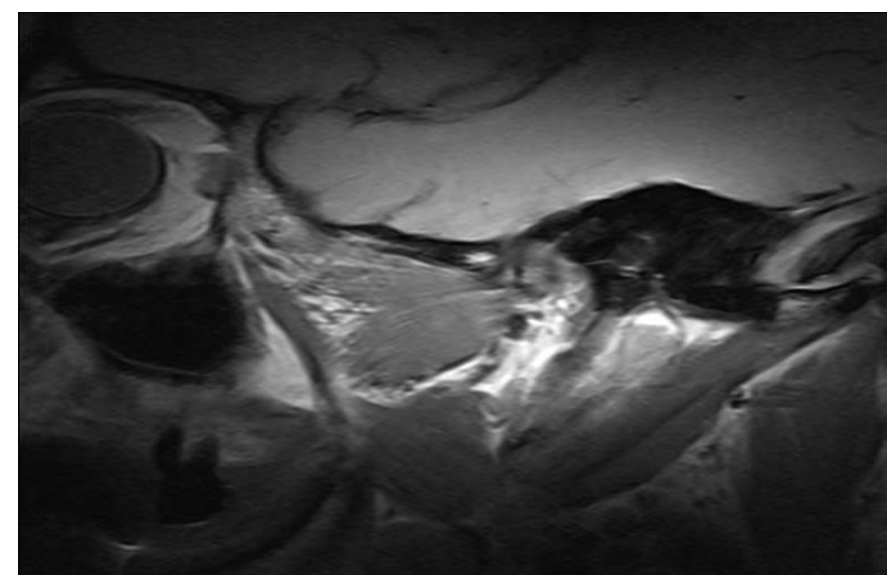

Fig. 5. MR imaging of the lateral pterygoid muscle in sagittal section

\subsection{Ultrasound}

Ultrasonography (USG) is an imaging technique that uses sound waves to examine soft tissue and parenchymal organs. This technique uses sound waves with frequencies well above the audible sound frequency (2-20 MHz). (Aldrich., 2007). Ultrasonography (USG) has been utilized in several areas of medicine. Recently, it has found use in dentistry for reasons such as being non-invasive, non-ionizing and enabling dynamic imaging. Although data on the use of orthodontics have increased in recent years, its use is still limited. USG can be used for purposes such as the evaluation of masticatory muscles (Close et al., 1995; Raadsheer et al., 1996; Bertram et al., 2001) (Fig. 6), the imaging of the TMJ region (Gateno et al., 1993) (Fig. 7), the evaluation of tongue volume and function (Shawker and Sonies, 1984; Wojtczak, 2012), the visualization of upper airway (Singh et al., 2010), the determination of soft tissue thickness at orthodontic miniscrew placement sites (Cha et al., 2008; Parmar et al., 2016), the evaluation of midpalatal suture (Sumer et al., 2012; Gumussoy et al., 2014) after RPE/SARPE procedures and the examination of changes in periodontal tissues (Zimbran et al., 2013).

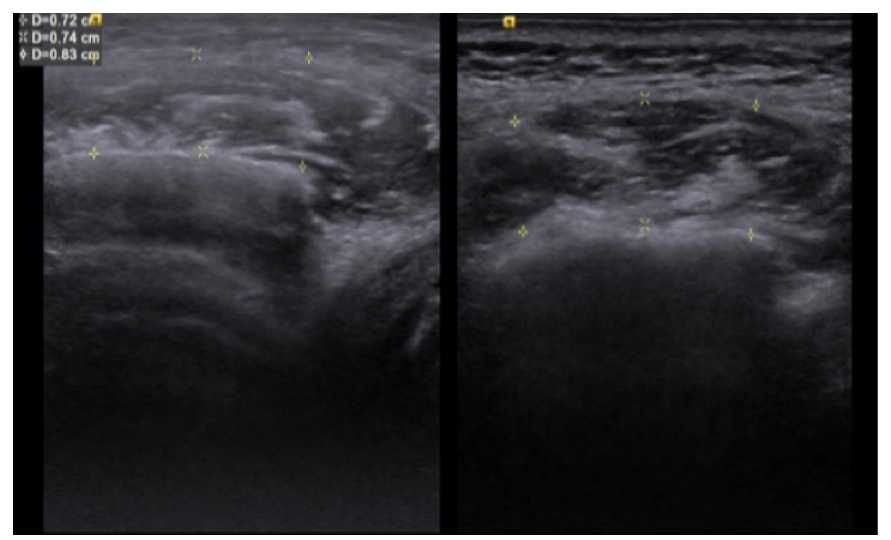

Fig. 6. Visualization of the masseter muscle by USG

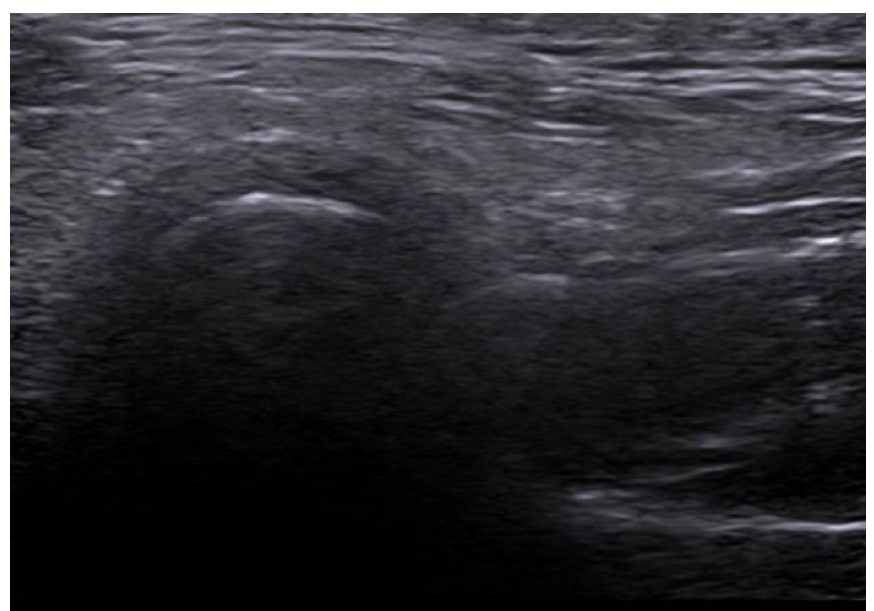

Fig. 7. Displaying the TMJ region by USG

USG is very useful in displaying the thickness and areas of the masticatory muscles and allows cross-sectional measurement of the muscles (Raadsheer et al., 1996; Close et al., 1995; Bertram et al., 2001). With USG, the length, thickness, cross-sectional area and volume measurements of the muscles can be performed (Durao et al., 2017). The most obvious disadvantage of the technique is that it allows only superficial muscles to be displayed. Therefore, ultrasound imaging of the lateral and medial pterygoid muscles is more difficult (Eren and Görgün, 2016). Another limitation of the technique is that the probe cannot cover the entire crosssectional area of the muscle. For this reason, many researchers measured the ultrasonographic thickness of the muscles instead of the cross-sectional areas (Kliaridis and Kalebo, 1991; Raadsheer et al., 1994; Raadsheer et al., 1996). In addition to the evaluation of masticatory muscles, USG is also used for the evaluation of tongue thickness, volume and function. 2D USG imaging is used for tongue function evaluation such as swallowing and speech as well as for estimating tongue thickness, and tongue volume (Shawker and Sonies, 1984; Wojtczak, 2012). 3D USG is performed for the evaluation of tongue function (Bressman et al., 2005).

In orthodontic treatment, miniscrews, placed inside the alveolar bone, are especially useful in cases where anchorage is critical. One of the factors affecting the stability of miniscrews is the thickness of the surrounding soft tissue. Cha et al. (2008) and Parmar et al. (2016) evaluated gingival tissue thicknesses with the help of USG and concluded that evaluation of the gingival tissues could help in selecting a proper miniscrew in orthodontic practice. In the current literature, there are also studies showing that USG use in the evaluation of midpalatal suture after RPE or SARME in patients with transversal maxillary deficiency (Sumer et al., 2012; Gumussoy et al., 2014). Although the results of these studies showed that the technique could be useful in imaging midpalatal sutures, it had not been possible to obtain certain results. 


\section{References}

1. Akçam, M.O., Altiok, T., Ozdiler, E., 2003. Panoramic radiographs: A tool for investigating skeletal pattern. Am. J. Orthod. Dentofacial Orthop. 123, 175-181.

2. Aldrich, J.E., 2007. Basic physics of ultrasound imaging. Crit. Care Med. 35, 131-137.

3. Altug-Atac, A.T., Erdem, D., 2007. Prevalence and distribution of dental anomalies in orthodontic patients. Am. J. Orthod. Dentofacial Orthop. 131, 510-514.

4. American Academy of Oral and Maxillofacial Radiology, 2013. Clinical recommendations regarding use of cone beam computed tomography in orthodontics. [corrected]. Position statement by the American Academy of Oral and Maxillofacial Radiology. Oral Surg. Oral Med. Oral Pathol. Oral Radiol. 116, 238-257.

5. Angle, E.H., 1899. Classification of malocclusion. Dental Cosmos. 41, 248-264.

6. Angle, E.H., 1907. Treatment of malocclusion of the teeth. SS White, Philadelphia.

7. Apajalahti, S., Peltola, J.S.,2007. Apical root resorption after orthodontic treatment a retrospective study. Eur. J. Orthod. 29, 408412.

8. Baccetti, T., Franchi, L., McNamara, J.A. Jr., 2002. An improved version of the cervical vertebral maturation (CVM) method for the assessment of mandibular growth. Angle Orthod. 72, 316-323.

9. Baccetti, T., Franchi, L., McNamara, J.A., 2005. The cervical vertebral maturation (CVM) method for the assessment of optimal treatment timing in dentofacial orthopedics. Semin. Orthod. 11, 119-129.

10. Bergman, R.T., 1999. Cephalometric soft tissue facial analysis. Am. J. Orthod. Dentofacial Orthop. 116, 373-389.

11. Bertram, S., Rudisch, A., Bodner, G., Emshoff, R., 2001. The shortterm effect of stabilization-type splints on the local asymmetry of masseter muscle sites. J. Oral Rehabil. 28, 1139-1143.

12. Björk, A., Helm, S., 1967. Prediction of the age of maximum puberal growth in body height. Angle Orthod. 37, 134-143.

13. Boom, H.P.W., Van Spronsen, P.H., Van Ginkel, F.C., Van Schijndel, R.A., Castelijns, J.A., Tuinzing, D.B., 2008. A Comparison of human jaw muscle cross-sectional area and volume in long and short-face subjects using MRI. Arch. Oral Biol. 53, 273-281.

14. Bowden, B.D.,1976. Epiphysial changes in the hand/wrist area as indicators of adolescent stage. Aust. Orthod. J. 4, 87-104.

15. Bressmann, T., Thind, P., Uy, C., Bollig, C., Gilbert, R.W., Irish, J.C., 2005. Quantitative three-dimensional ultrasound analysis of tongue protrusion, grooving and symmetry: Data from 12 normal speakers and a partial glossectomee. Clin. Linguist Phon. 19 (6-7), 573-588.

16. Brown, M.A., Semelka, R.C., 1999, MRI: Basic Principles and Applications. Second Edition. Wiley-Liss Ltd, New York. Brown, M.A., Semelka, R.C., 1999, MRI: Basic Principles and Applications. Second Edition. Wiley-Liss Ltd, New York.

17. Cattaneo, P.M., Bloch, C.B., Calmar, D., Hjortshøj, M., Melsen, B., 2008. Comparison between conventional and cone-beam computed tomography-generated cephalograms. Am. J. Orthod. Dentofacial Orthop. 134, 798-802.

18. Cesur, E., Özdiler, O., Köklü, A., Orhan, K., Seki, U., 2020. Effects of wear time differences of removable functional appliances in class II patients: prospective MRI study of TMJ and masticatory muscle changes. Oral Radiol. 36, 47-59.
19. Cha, B.K., Lee, Y.H., Lee, N.K., Choi, D.S., Baek, S.H., 2008. Soft tissue thickness for placement of an orthodontic miniscrew using an ultrasonic device. Angle Orthod. 78, 403-408.

20. Chaconas, S.J., Fragiskos, F.D., 1991. Orthognathic diagnosis and treatment planning: A Cephalometric Approach. J. Oral Rehab. 18, 531-545.

21. Close, P.J., Stokes, M.J., L'Estrange, P.R., Rowell, J., 1995. Ultrasonography of masseter muscle size in normal young adults. J. Oral Rehabil. 22, 129-134.

22. Dalessandri, D., Laffranchi, L., Tonni, I., Zotti, F., Piancino, M.G., Paganelli, C., Bracco, P., 2011. Advantages of cone beam computed tomography (CBCT) in the orthodontic treatment planning of cleidocranial dysplasia patients: a case report. Head Face Med. 7, 6.

23. Dudic, A., Giannopoulou, C., Leuzinger, M., Kiliaridis, S., 2009. Detection of apical root resorption after orthodontic treatment by using panoramic radiography and cone-beam computed tomography of super-high resolution. Am. J. Orthod. Dentofacial Orthop. 135, 434-437.

24. Durao, A.P.R., Morosolli, A., Brown, J., Jacobs, R., 2017. Masseter muscle measurement performed by ultrasound: a systematic review. Dentomaxillofac. Radiol. 46, 20170052.

25. Ejima, K., Schulze, D., Stippig, A., Matsumoto, K., Rottke, D., Honda, K., 2013. Relationship between the thickness of the roof of glenoid fossa, condyle morphology and remaining teeth in asymptomatic European patients based on cone beam CT data sets. Dentomaxillofac. Radiol. 42, 90929410.

26. Eley, K.A., McIntyre, A.G., Watt-Smith, S.R., Golding, S.J., 2012. 'Black bone" MRI: A partial flip angle technique for radiation reduction in craniofacial imaging. Br. J. Radiol. 85(1011), 272-278.

27. Eley, K.A., Watt-Smith, S.R., Golding, S.J., 2013. "Black Bone" MRI: A potential non- ionizing method for three-dimensional cephalometric analysis a preliminary feasibility study. Dentomaxillofac. Radiol. 42, 20130236.

28. Emshoff, R., Bertram, S., Brandlmaier, I., Scheiderbauer, G., Rudisch, A., Bodner, G., 2002. Ultrasonographic assessment of local cross-sectional dimensions of masseter muscle sites: A reproducible technique? J. Oral Rehabil. 29, 1059-1062.

29. Eren, H., Görgün, S., 2016. Çiğneme kaslarının değerlendirilmesinde ultrason kullanımı. Turkiye Klinikleri Journal of Oral and Maxillofacial Radiology-Special Topics. 2, 16.

30. Erten, O., Y1lmaz, B.N., 2018. Three-dimensional imaging in orthodontics. Turk. J. Orthod. 31, 86-94.

31. Erverdi, N., 2017. Malokluzyonların sınıflamasının: Çağdaş Ortodonti First Edition. Erverdi, N., ed. Quintessence Pub., İstanbul.

32. Fishman, L.S., 1979. Chronological versus skeletal age, an evaluation of craniofacial growth. Angle Orthod. 49, 181-189.

33. Fishman, L.S.,1982. Radiographic evaluation of skeletal maturation; a clinically oriented method based on hand-wrist films. Angle Orthod. 52, 88-112.

34. Flores-Mir, C., Burgess, C.A., Champney, M., Jensen, R.J., Pitchere, M.R., Major, P.W., 2006. Correlation of skeletal maturation stages determined by cervical vertebrae and hand-wrist evaluations. Angle Orthod. 76, 1-5.

35. Flores-Mir, C., Nebbe, B., Major, P.W., 2004. Use of skeletal maturation based on hand-wrist radiographic analysis as a predictor of facial growth: A systematic review. Angle Orthod. 74, 118-124.

36. Garib, D.G., Yatabe, M.S., Ozawa, T.O., Filho, O.G., 2012. 
Alveolar bone morphology in patients with bilateral complete cleft lip and palate in the mixed dentition: cone beam computed tomography evaluation. Cleft Palate Craniofac. J. 49, 208-214.

37. Gateno, J., Miloro, M., Hendler, B.H., Horrow, M., 1993. The use of ultrasound to determine the position of the mandibular condyle. J. Oral Maxillofac. Surg. 51, 1081-1086.

38. Gill, D.J., Naini, F.B., 2011, Orthodontics: Princeples and Practice. First edition. Wiley-Blackwell, Oxford.

39. Graber, T.M., 1967. Panoramic radiography in orthodontic diagnosis. Am. J. Orthod. 53, 799-821.

40. Greulich, W.W., Pyle, S.I., 1959. Radiographic atlas of skeletal development of hand and wrist. Second edition. Stanford University Press, Stanford, California.

41. Gumussoy, I., Miloglu, O., Bayrakdar, I.S., Dagistan, S., Caglayan, F., 2014 Ultrasonography in the evaluation of the mid-palatal suture in rapid palatal expansion. Dentomaxillofac. Radiol. 43, 20140167.

42. Hans, M.G., Palomo, J.M., Valiathan, M., 2015. History of imaging in orthodontics from Broadbent to cone-beam computed tomography. Am. J. Orthod. Dentofacial Orthop. 146, 914-921.

43. Hassel, B., Farman, A.G., 1995. Skeletal maturation evaluation using cervical vertebrae. Am. J. Orthod. Dentofacial Orthop. 107, 58-66.

44. Heil, A., Lazo Gonzalez, E., Hilgenfeld, T., Kickingereder, P., Bendszus, M., Heiland, S, et al., 2017. Lateral cephalometric analysis for treatment planning in orthodontics based on MRI compared with radiographs: A feasibility study in children and adolescents. PLoS ONE 12(3), e0174524.

45. Holdaway RE., 1983. A soft-tissue cephalometric analysis and its use in orthodontic treatment planning. Part I. Am. J. Orthod. 84, 128.

46. Katheria, B.C., Kau, C.H., Tate, R., Chen, J.W., English, J., Bouquot, J., 2010. Effectiveness of impacted and supernumerary tooth diagnosis from traditional radiography versus cone beam computed tomography. Pediatr. Dent. 32, 304-309.

47. Kayasu, T., Köklü, A., 2012. Denture frame analizi'nin toplumumuzdaki normlari ve vertikal yön etkinliği. Ankara University Health Sciences Institution, $\mathrm{PhD}$ Thesis.

48. Kingsley, N.W., 1880. Oral Deformities. Appleton \& Son Co., New York.

49. Konez, O., 1995. Manyetik Rezonans Görüntüleme. First Edition. Nobel Tip Kitapevleri, İstanbul.

50. Lamparski, D.G., 1972. Skeletal age assessment utilizing cervical vertebrae. Department of Orthodontics, The University of Pittsburgh, Master's Thesis.

51. Markic, G., Müller, L., Patcas, R., Roos, M., Lochbühler, N., Peltomäki, T., Karlo, C.A., Ullrich, O., Kellenberger, CJ., 2015. Assessing the length of the mandibular ramus and the condylar process: A comparison of OPG, CBCT, CT, MRI, and lateral cephalometric measurements, Eur. J. Orthod. 37, 13-21.

52. McNamara Jr, J.A., Franchi, L., 2018. The cervical vertebral maturation method: A user's guide. Angle Orthod. 88, 133-143.

53. Mozzo, P., Procacci, C., Tacconi, A., Martini, P.T., Andreis, I.A., 1998. A new volumetric CT machine for dental imaging based on the conebeam technique: preliminary results. Eur. Radiol. 8, 15581564.

54. Navarro, R.L., Oltramari-Navarro, P.V., Fernandes, T.M., Oliveira, G.F., Conti, A.C., Almeida, M.R., Almeida, R.R., 2013. Comparison of manual, digital and lateral CBCT cephalometric analyses. J. Appl. Oral Sci. 21, 167-176.

55. Nohadani, N., Ruf, S., 2008. Assessment of vertical facial and dentoalveolar changes using panoramic radiography. 30, 262-268.

56. Oenning, A.C., Jacobs, R., Pauwels, R., Stratis, A., Hedesiu, M., Salmon, B., 2018. DIMITRA Research Group. Cone-beam CT in paediatric dentistry: DIMITRA project position statement. Pediatr. Radiol. 48, 308-316.

57. Orhan, K., Ucok, O., Delilbas1, C., Paksoy, C., Doğan, N., Karakurumer, K., Ozen, T., 2005. Prevaence of temporomandibular joint sideways disc displacement in symptomfree volunteers and comparison of signal intensity ratios of masticator muscles on magnetic resonance 1mages. Oral Health and Dental Management in Black Sea Countries. 1, 14-18.

58. Orhan, K., Nishiyama, H., Tadashi, S., Murakami, S., Furukawa, S., 2006. Comparison of altered signal intensity, position, and morphology of the tmj disc in mr images corrected for variations in surface coil sensitivity. Oral Surg. Oral Med. Oral Radiol. Endod. $101,515-522$.

59. Orhan, K., Aksoy, S., 2015. Konik 1şınlı bilgisayarlı tomografi ile 3 boyutlu sefalometri. In: Güncel bilgiler ışığında ortodonti. First Edition. Ozdiler, E., ed. Gümüş Kitabevi, Ankara.

60. Oyar, O., 2008. Magnetik rezonans görüntüleme (MRG)'nin klinik uygulamaları ve endikasyonları. Harran Üniversitesi Tıp Fakültesi Dergisi. 5, 31-40.

61. Ozbek, S.V., Orhan, K., Öztürkmen, Z., 2016. Manyetik rezonans görüntülemenin diş hekimliğindeki yeri, önemi ve manyetik rezonans görüntülerinin yorumlanması. Türkiye Klinikleri J. Oral Maxillofac. Radiol. Special Topics. 2, 33-36.

62. Pacini, A.J., 1922. A System Roentgen Anthropometri, (The Skull). J Radiol. 3, 230-238, 322-331, 418-426. From: Gazilerli, Ü., 1976. Normal Kapanışlı 13-16 Yaşlar Arasındaki Ankara Çocuklarında Steiner Normları. Doçentlik Tezi. Ankara.

63. Palomo, J.M., Yang, C.Y., Hans, M.G., 2005. Clinical application of three-dimensional craniofacial imaging in orthodontics. J. Med. Sci. 25, 269-278.

64. Pancherz, H., Ruf, S., Thomalske-Faubert, C., 1999. Mandibular articular disc position changes during herbst treatment: A prospective longitudinal MRI study. Am. J. Orthod. Dentofacial Orthop. 116, 207-214.

65. Parmar, R., Reddy, V., Reddy, S.K., Reddy, D., 2016. Determination of soft tissue thickness at orthodontic miniscrew placement sites using ultrasonography for customizing screw selection. Am. J. Orthod. Dentofacial Orthop. 150, 651-658.

66. Proffit, W.R., 2013. Concepts of growth and development. In: Contemporary Orthodontics. Fifth Edition. Proffit, W.R., Fields, H.W., Sarver, D.M., eds. Mosby Company, St. Louis.

67. Raadsheer, M.C., Van Eijden, T.M., Van Spronsen, P.H., Van Ginkel, F.C., Kiliaridis, S., Prahl-Andersen, B., 1994. A comparison of human masseter muscle thickness measured by ultrasonography and magnetic resonance imaging. Arch. Oral Biol. $39,1079-1084$.

68. Raadsheer, M.C., Kiliaridis, S., Van Eijden, T.M., Van Ginkel, F.C., Prahl-Andersen, B., 1996. Masseter muscle thickness in growing individuals and its relation to facial morphology. Arch. Oral Biol. 41, 323-332.

69. Ruf, S., Pancherz, H., 1998. Temporomandibular joint growth adaptation in Herbst treatment: A prospective magnetic resonance imaging and cephalometric roentgenographic study. Eur. J. Orthod. $20,375-388$.

70. Ruf, S., Wüsten, B., Pancherz, H., 2002. Temporomandibular joint effects of activator treatment: Aprospective longitudinal magnetic 
resonance imaging and clinical study. Angle Orthod. 72, 527-540.

71. Sharath Kumar, S., S.K., Neeraje, U., Mahesh Kumar, Y., Vivek, V., 2017. CBCT in orthognathic surgery. Sch. J. Dent. Sci. 4, 547555 .

72. Shawker, T.H., Sonies, B.C., 1984. Tongue movement during speech: A real-time ultrasound evaluation. J. Clin. Ultrasound. 12, 125-133.

73. Singh, M., Chin, K.J., Chan, V.W., Wong, D.T., Prasad, G.A., Yu, E., 2010. Use of sonography for airway assessment: an observational study. J. Ultrasound Med. 29, 79-85.

74. Sumer, A.P., Ozer, M., Sumer, M., Danaci, M., Tokalak, F., Telcioglu, N.T., 2012. Ultrasonography in the evaluation of midpalatal suture in surgically assisted rapid maxillary expansion. J. Craniofac Surg. 23, 1375-1377.

75. Sümbüllü, M.A., Caglayan, F., Akgül, H.M., Yilmaz, A.B., 2012. Radiological examination of the articular eminence morphology using cone beam CT. Dentomaxillofac. Radiol. 41, 234-240.

76. Quintero, J.C., Trosien, A., Hatcher, D., Kapila, S., 1999 Craniofacial imaging in orthodontics: historical perspective, current status, and future developments. Angle Orthod. 69, 491506.

77. Tanner, J.M., Whitehouse, R.H., Cameron, N., Marshall, W.A., Healy, M.J.R., Goldstein, H., 1983, Assessment of skeletal maturity and prediction of adult height (TW2 Method). Second Edition. Academic Press, London.
78. Türköz, Ç., Kaygısız, E., Ulusoy, Ç., Ateş, C., 2017. A practical formula for determining growth. Diagn. Interv. Radiol. 23, 194198.

79. Uzel, İ., Enacar, A., 2000. Ortodontide Sefalometri. Çukurova Üniversitesi Basımevi, Adana.

80. Ülgen, M., 2001. Ortodonti anomaliler, sefalometri, etiyoloji, büyüme ve gelişim, tanı. Ankara Üniversitesi Diş Hekimliği Fakültesi Yayınları, Ankara.

81. Van Vlijmen, O.J., Maal, T., Berge, S.J., Bronkhorst, E.M., Katsaros, C., Kujipers-Jagtman, A.M., 2010. A comparison between 2D and 3D cephalometry on CBCT scans of human skulls. Int. J. Oral and Maxillofac. Surg. 39, 156-160.

82. White, S.C., Pharoah, M.J., Goaz, P.W., 2000. Oral radiology: Principles and interpretation. Fourth Edition. Mosby Company, St. Louis.

83. Wojtczak, J.A., 2012. Submandibular sonography: Assessment of hyomental distances and ratio, tongue size, and floor of the mouth musculature using portable sonography. J. Ultrasound Med. 31, 523-528.

84. Zimbran, A., Dudea, S., Dudea, D., 2013. Evaluation of periodontal tissues using $40 \mathrm{MHz}$ ultrasonography. preliminary report. Med. Ultrason. 15, 6-9.

85. Zimmerman, J.N., Vora, S.R., Pliska, B.T., 2019. Reliability of upper airway assessment using CBCT. Eur. J. Orthod. 41, 101-108. 